\title{
Geographical contribution of contemporary labour migration from Serbia and Montenegro to Denmark
}

\author{
Goran Rajović \\ IDIS, \\ Street Vojvode Stepe 252, Belgrade, Serbia \\ E-mail: dkgoran.rajovic@gmail.com
}

\begin{abstract}
The following text is a contribution to the study of contemporary geographical migration of labour force from Serbia and Montenegro in Denmark. The time frame for the study covers the period from the mid ' 60 s to the dissolution of the State Union of Serbia and Montenegro in 2006. Some data relates to the period after 2006, and for which we believed to be relevant to the investigation. The focus of attention is focused on four groups of issues: the causes of migration, information about employment opportunities, and the massive flow of migration and residency in Denmark and material effects of migration. Communities of immigrants from Serbia and Montenegro, although not many (about 8,000 ), is interesting for researchers, because in the middle of Denmark that is economically dependent, maintained their ethnic or social identity. Denmark is a prime example of the state where the persistent and deliberate work, culture and democracy achieved legally, economically, socially stable society, appealing to other countries and peoples. In such a society that I have found my place and migrants from Serbia and Montenegro, and that the Danes have a lot of sympathy, it is understandable when the Danes themselves strike correctness of Slovenia's emotions.
\end{abstract}

Keywords: Serbia and Montenegro; Denmark; migration; migrants.

Reference to this paper should be made as follows: Rajović, G. (2014) 'Geographical contribution of contemporary labour migration from Serbia and Montenegro to Denmark', Int. J. Migration and Residential Mobility, Vol. 1, No. 1, pp. $28-49$.

Biographical notes: Goran Rajović completed his elementary and high school educational pedagogy in Andrijevica. He graduated in 1992 at the University of Montenegro, Faculty of Philosophy in Nikšić. His educational profile are - a Professor of History and Geography. MSc degree in 1995 at the University in Belgrade, Faculty of Science, Faculty of Geography. Dr 2004, University of Novi Sad, Faculty of Science, Department of Geography, Tourism and Hotel Management. From 25.09 in 1995 to 15.03 in 2004, he held positions of Professor of Geography in elementary school 'Mladost', School for Beauty Care and the Geological and Hydro Meteorological School 'Milutin Milanković' in Belgrade. From 15.03 in 2004, he is working in a private sector in Belgrade with occasional stays in Copenhagen.

\section{Introduction}

Lee (1966) singled out four groups of factors that influence the decision to migrate:

Copyright (C) 2014 Inderscience Enterprises Ltd. 
1 factors associated with the area of origin

2 factors associated with the area of destination

3 possible barriers to migration between areas of origin and destination, such as distance, physical barriers, and immigration laws

4 personal factors that modify the migrants themselves other factors in terms of migration decisions.

Lee (1966) also argues that migration tend developments in the form of clearly defined currents, from specific places at specific places of origin, destination, and not just because the potential for migration generally highly localised, but the return flow of knowledge and information from the destination to the place of origin to the passage of later migrants.

Castels (2006) outlines three stages of labour migration. First, a massive labour migration in countries of is capitalist economy. Second, the 'family reunification', begins when workers, to reduce isolation, save money and makes life easier for the foreign community, they bring their spouses and children, or a new family based. In a situation where migrants are beginning to found a family and when their children start attending Western European schools, Castels (2006), concludes that migrants can then decide in most cases you will. The third stage is the stage at Castels 'permanent settlement' and the development of new ethnic minorities. Labour migration from Serbia and Montenegro in Denmark, did not cease even to this day.

The question now is what the proper term is for the workers: 'Foreign workers', 'migrant workers abroad', 'immigrants', 'Diaspora'. Guest worker ('guest worker', a word which in German means both singular and plural) is a term that has different connotations, both positive and negative, in the ethnic, social, cultural and economic context. Primarily, it means are guest workers, or people who, in the ' 60 s and ' 70 s of our last century came abroad in search of work. Yugoslav workers went to Denmark with the intention of returning soon, years have delayed return to Denmark they were born, and children and grandchildren, are now a few years to retirement or already retired, but still will not be returned or partially returned ... Temporality turned into permanence. And, and, once they return, they are not completely 'at home', something they lack.

Čapo-Šmegić (2006) points out:
"In a theoretical sense, it is wrong to speak of 'migrant workers', though, if you think about it, it still avoids actually say that they are immigrants. The term 'immigrant' means namely definitely eviction. The appointment of our people are still feeling the effect of the communist regime, who coined the term 'migrant workers abroad ......'. Why? Because nineteen sixties, when the pressure of unemployment and growing social tensions in the former Yugoslavia was growing, party authorities of the Socialist Federal Republic of Yugoslavia were forced to react somehow - because people are not able to offer the job open until then closed borders, and create jobs overseas, the capitalist West. In those years the external migration - indeed paradoxical and defeating the then current ideology - has become the normal form of employment of Yugoslav workers. So called 'temporary' because people call these immigrants would mean to admit the failure of socialism, to achieve full employment society".

In Denmark, however, even the '80s, there was a change in terminology and more often instead of the term guest worker, began to use the term 'foreign workers' ('udenlandske 
arbejdstagere'). According to Spasović and Miletić (2010), the term 'Diaspora' is usually used in a religious and ecclesial sense, and almost the "60s and '70s was not in use. The word Diaspora has found increasing application only since the ' 90 s onwards, I meant the citizens of Serbia and Montenegro, who live outside its borders in the world, although it has existed for a second term Serbian - spread. However, we believe that today, more correct to speak of immigrants, or immigrants, and increasingly in the international literature and international meets Migrants word.

Communities of immigrants from Serbia and Montenegro, but not many (about 8,000 ), is interesting for researchers, because in the middle of Denmark that is economically dependent, maintained their ethnic or social identity. In the study were taken into account all three generations of immigrants from Serbia and Montenegro, and the survey covers the period from the mid-' 60 s, this is the first generation of the arrivals of Serbian and Montenegrin immigrants to Denmark, to the dissolution of the State Union of Serbia and Montenegro worse in 2006. Some data includes the period after 2006, for which we considered necessary for the research (Rajović, 2013).

\section{Research methodology}

Two main groups of data sources were used in the study. The first group includes data based on the survey and interview. Being is result of years of research by the text, for monographs 'Migrants from Serbia and Montenegro to Denmark'. Due to the disorder of are data in this paper showing partial data, which is related to the characteristics of contemporary labour migration from Serbia and Montenegro in Denmark. The second group of data makes the results of previous studies, published in both local and in the international literature. The literature includes: textbooks, monographs, proceedings, journals... Were studied and written sources on the internet.

The scientific explanation of terms, we applied three methods: chorological, historical and genetic system. For more complex understanding of complex issues of migration was necessary and the application of the concept of interdisciplinary studies, which was based on the methods and results of other scientific disciplines: anthropology, sociology, demography, economy, history, psychology.... Statistical method is particularly important in the cultural and geographic and demographic research, and therefore is infallible and in the study of migration. However, the application of this method was limited character. According to him Nikitović (2009), migration is a phenomenon that is difficult to predict, especially in countries such as Serbia and Montenegro. There are several reasons for this, and they can be classified into two main groups. The first is related to the poor quality of data on external migration, and the other to strong political and economic dependence of migration flows. Official data not cover all immigrants from Serbia and Montenegro, thanks to the people who go out of the country often does not report a change of residence. Intermediate conclusion on their number can be derived based on the data of countries receptor, but it only applies to individuals who are registered. Future that is us interested in a subjective or personal experiences of migrants, in this paper transfer 'life story' of migrants. After all, 'life stories' of migrants are subjects of research many authors (Stahl, 1977; Clements, 1980; Titon, 1980; Robinson, 1981; Bošković-Stulli, 1984; Jambrešić-Kirin, 1995; Stark, 2005; Kovačević and Krstić, 2011). 


\section{Analysis and discussion}

The study of migration movements, are exceptionally area of scientific research. In addition, there is a large socio-economic interest, to carry out such research. So great interest, arising from are fact that the issues related to migratory movements, very important in any society, especially in Serbia and Montenegro. The issue of migration movements deal with: demographers, economists, urban planners, sociologists, anthropologists, historians, and many others, which just shows that deals with this issue and geography, recognising that geography is correlative science - science that successfully connects research fields of natural and social sciences and in many areas of research synthesis has significance(Rajović, 1999).

Numerous researchers from Serbia and Montenegro in their theoretical works devoted particular attention to the issue of immigration and determining the legality of its changes, creating a rich scientific base is necessary for the determination of further research. Dealing with the analysis of migration in different temporal and spatial framework, researchers from Serbia and Montenegro, as the complex socio-economic process, observed with several aspects, either directly or in the analysis of the overall socio-economic development (Rajović, 2001).

However, many authors in the world, as on this occasion emphasise this: De Hass (2005), Kuznetsov (2006), Brettell and Hollifield (2007), Skeldon (2008)... point out that although studies of international migration movements, lasting more than a hundred years, it does not give satisfactory results and clear positions on some basic issues, such as:

1 How to develop migration flows and can they be predicted?

2 How to manage state migration?

3 Is way to harmonise development policies of countries with global migration trends?

4 How and in what way to take advantage of potential migration?

So, in the study of migration flows, the issues are numerous and extremely complex problems. At the same time in such a complex situation, responsibility of science to society is increasing and is expected to solutions of current problems of migration.

However, many authors in the world, as on this occasion emphasise this issue. De Hass (2005), Kuznetsov (2006), Brettell and Hollifield (2007), and Skeldon (2008) agreed that although studies of international migration movements, lasting more than a hundred years, it does not give satisfactory results and clear positions on some basic issues. For example:

a How to develop migration flows and can they be predicted?

b How to manage state migration?

c Is way to harmonise development policies of countries with global migration trends?

d How and in what way to take advantage of potential migration.

So, in the study of migration flows, the issues are numerous and extremely complex problems. At the same time, responsibilities of circles of academics and policy in such a complex situation are increasing and is expected to solve current problems of migration. 
Penev and Predojević-Despić (2012) suggest that it is the lack of reliable information containing data on migration between the countries of origin and destination, and regional origin, demographic and socio-economic structures of migrants, preventing not only more reliable reading of theoretical approaches to the detection of deterministic basis of migration, but a more detailed analysis of the complex relationship of social development and migration, particularly in the area of finding a political response to the possibility of using migration (foreign remittances, translational migrant networks, social and human capital) to promote socio-economic development in the host countries and countries of origin.

Without analysing, what each of the disciplines in the interdisciplinary study of migration as part of the migration and can be done, the question is: to what extent migration as a process, a subject of geography? Based on the fact that, along with other migratory movements, emigration is not only human but also geographical mobility, as it takes place in a certain area, it seems that the geography, the most appropriate primary or connect the entire complex, which belongs to the domain of external migration (Banović, 1982).

So Rodić (1972) believes that when studying migration as part of the migration, attention should be paid to six parts. Should be studied:

1 the causes of migration

2 information about employment opportunities

3 flow and mass migration

4 stay abroad I material effects of migration

5 return of workers into the country, thus ending the cycle and migration

6 workers living at home after returning from abroad.

We have set ourselves a modest task, in this article we highlight the first four sets of questions, related to the migrants from Serbia and Montenegro in Denmark. Therefore, do not pretend to exhaust all the problems, which refer to a group of fifth and sixth issues, the main reason, because it is almost a symbolic return of migrant workers to their home countries. Namely, according to Rajović (1993) and Rajović (2011a), a total of 51 Montenegrin migrants returned from Denmark to Montenegro. We can safely assume that the number of workers, who have returned from Denmark to Serbia, almost minimal. On his return home, we noticed that the worker returnee starts life with his family in the same place, or changing residence in Montenegro. Usually, earned money, solve housing problems or purchased machinery and other equipment to ensure further existence. For most workers returning, present remorse, erroneous decisions about departure from Denmark (Rajović, 2000).

\subsection{Causes of migration}

In the second half of the 20th century, there was an exodus of the Serbian and Montenegrin labour force in various countries of the world. One of these countries was Denmark. Emigration took place, mostly for economic reasons. However, the level of emigration was influenced by events in the former Yugoslavia, especially wars and sanctions. Here is an example for this. In fact, after the Second World War the former 
Yugoslavia has been turned into a huge construction site. Revolutionaries were accepted by the masses of rehabilitation and reconstruction (1945 to 1950) that is all that is destroyed in the war. In this period was 'full employment'. Such allocation of labour lasted until the early ' $50 \mathrm{~s}$. After that, under the pressure of economic inefficiency, was followed by the partial decentralisation of the economic system is guided by the so-called 'self-managed socialism' (Horvat, 1996). However, the economic blockade (1948 to 1954) and a dry year, affected the pace of capital construction. This resulted in the reduction of the use of existing capacity and declining employment dynamics of the workforce. Economic reform (since 1965), encouraged rational economic activity, it is the total labour supply could be absorbed, with the horizon, that the company is due relatively expensive capital for deciding capital intensive technologies (Rodić, 1971). According to Lebowitz (2010), self-managed companies have lain off workers, but also have opened up a lot of jobs. Why? Because are performed intensive capital investment. The workers came from the countryside to the city attracted by higher wages, but they could not find a job. In front of this situation began to immigrate to Western Europe. The unemployment rate in Yugoslavia 1971 year was 7\%, but this should be added a further $20 \%$ of the workforce worked abroad.

Tomaš (1993) and Milanović (1990) suggest that the system of self-management socialism, which was formally established in the mid-'70s, has affirmed the concept of 'pooling of labour'. In practical terms, since there is no private property, that there is no labour market, but to freely 'join the work'. However, despite the official denial of the existence of the labour market that is virtually certain form still existed. There is actually a fragmentation of national and local labour market on a large number of small and, by their nature, almost a monopoly of organised markets closed. High job security prevented the action mechanism of market competition and coercion. There was no pressure on the employed workers to increase efficiency which has led to the realisation that for the same volume of production workers hired significantly more than in the classical (entrepreneurial) firms. The economic impact was expected: since the mid-'70s to the complete collapse of the economic system at the end of the ' $80 \mathrm{~s}$, labour productivity has been declining, and hidden unemployment was rising.

Here, we have one of the most important problems in self-management of the former Yugoslavia did not fix: the inability to eliminate the problem of inequality. One consequence of this unresolved situation was reflected in the fact that the poorest sector workers tended increasing its revenue more than the circumstances that justified the enterprise. But in this case, how the company could finance the poorest? Through are loans bank. The poorest enterprises finance their investments and bank loans that turned into one of the sources of inflation. All this has created serious problems such as unemployment, inequality, inflation. During the $70 \mathrm{~s}$, the former Yugoslav companies were able to get a lot of money in the form of loans from Western banks. Loans should be used for investment in the modernisation of firms and were taken with an opinion that could be exported to Western Europe. But the ' 80 s of the last century characterised the decline of global capitalism. In these circumstances, companies had to reverse this problem loans. Suddenly, Yugoslavia was discovered to have a substantial external debt. To make loans to the reconstruction of the former Yugoslavia as a state should take responsibility for the debt and had to pay interest due (at high rates in place in the ' $80 \mathrm{~s}$ ). Between are 1984 and 1988, the former Yugoslavia has paid the debt of 14 billion dollars in interest. The cost of $40 \%$ of export earnings had to be repaid, the debt. And with the 
diversion of export revenue increased inflation due to the inability to import, lack of income..... (Lebowitz, 2010).

Furthermore, the ' 90 s of the last century represent an extremely complex period in the socio-economic life of the population of the Federal Republic of Yugoslavia (Serbia and Montenegro). "The disintegration of the former Yugoslavia, the war in the region, the sanctions of the international community, the social and political changes, the deep economic crisis, military intervention, political developments, institutional crisis.... Feeling is, above all, economic and existential insecurity is main features of life during this period, both are individual and psychological new" (Tucović and Stevanović, 2007). Despite the formal existence of some market policies in the country, it is in the economic life are not respected. In practice, it is dominated by legal uncertainty, mismanagement of contracts, inability to collect receivables. Even the state did not comply with the rules laid down for its own (Madžar, 2000). Thus, creating and maintain confidence in the institution. These processes have left a deep mark on the complete functioning of the economy and, consequently, the problems of labour and employment (Stojanović, 2005). According to Stojanović (2005), economy in the period 1990 to 2000, characterised by: a drastic decline in production and GDP (about 40\% of its level in 1989), a high percentage of 'Gray economy' highly formal and hidden unemployment, broken banking system, technological backwardness and economic isolation. Number of vacancies (or the demand for labour) was on average 24 times less than the number of unemployed (labour supply) in 1991, and 21 times less in 2000. The causes of mass unemployment in this period are as follows: a low level of economic activity, and the absence of new investment, globally speaking, and the absence of radical market reforms.

After 2000, as well as many other countries in transition and in the Federal Yugoslavia economic model, according Dušanić (2011) was based on (RAS) asset sales, borrowing, importing and consumption which is inevitably produced deficits (foreign trade, budget...). According to official data of the Statistical Office of Serbia, the number of employees in Serbia at the beginning of 2011 was smaller in absolute terms than in $2001(1,816,959$ to $2,101,668)$. Serbia has a dramatically lower employment rate (percentage of the population between 15 and 64 years, who has a job) of only $38 \%$ (in developed countries it is about $70 \%$ ). Low savings and high consumption and investment (which is enabled by the sale of state property and additional borrowing abroad), high unemployment (instead of growth, constant downsizing), absence of substantial economic restructures (limited mostly to layoffs) and ineffective corporate governance (framing of the parties and large discretionary rights which are accompanied by corruption, nepotism...), prevented the expected long-term sustainable economic growth.

The programme of economic modernisation should be an integral part of a comprehensive and consistent programme, which is supposed to stop the serious deterioration of the economy and society as a whole, and the country move toward renewal and prosperity. Therefore, a well-developed and implemented a programme of economic modernisation will not be able to provide the desired results unless it is accompanied by a consistent and coordinated reforms in other spheres of social life. The main (main) goal of economic policy should be to improve the well-being and quality of life, dynamic long-term sustainable economic growth with full employment and equitable and fair distribution of national income under the assumption objectives and achieve the main goal - improving the welfare and quality of life (Dušanić, 2011).

In conclusion, as we note from the above stated article: underdevelopment, poor living conditions and lack of employment are the most important reasons why people 
choose to leave their country. Famous economist J.K. Galbraith migration is interpreted as 'the oldest action against poverty' (Group by, 2006). In the second half of the 20th century, therefore, there was a mass exodus of the Serbian and Montenegrin labour force in various countries of the world. The former state has failed to create a reliable economic and social system, and provide safe opportunities for work and a dignified life. As so many times before, the Serbian and Montenegrin labour has gone in the direction of expansion of global capital in the direction of Western Europe (Germany, France, England, Denmark, Sweden and other European countries) and the USA. Some could not in the system without rules, find their economic position and went, in search of bread, in a richer environment. Second, they had the knowledge and security that they can succeed in the toughest environments, so they went in order to secure a life, what in the world labour market and merit, avoiding completely insecure and uncertain penetration in the mainstream (Vukčević, 2006). Among these migrants were certainly migrants from Serbia and Montenegro to Denmark, who in this Promised Land led their family, or have acquired there. Some today, received the citizenship of the country in which they work.

\subsection{Information on employment opportunities}

Information on conditions and employment opportunities in Denmark, it is important to start the migration. The media: radio, television, newspapers, informing the citizens about the employment and salaries in Denmark. In that same the other way, 'the story' and here we mean those who have already arrived in the Promised Land, and transfer the information to their homeland, interested parties are given the opportunity of learning all the details out. So from the mid-' 60 s to the early ' 90 s of the last century, leaving room and labour from Serbia and Montenegro in Denmark, it was done without any difficulty.

The departure of workers to 'work abroad' began making 'instructions on the procedure for employment of migrant workers abroad', the 1963 year, where workers from the region of former Yugoslavia to legally go abroad. It is through the media, as a migrant from Serbia and Montenegro, came to full knowledge of going abroad. Mass media in are 'near' meeting the daily information to the public and 'indulging individual' to independently review information about going abroad. The question then was how many people really believed information that is published by the mass media and how they are interpreted, that is, the way that they were understood. Of course, all this is dependent on factors such as age, gender, level of education...

Namely, in order to better protect the employees abroad, the former Yugoslavia, in 1973, brings the 'Law about basic conditions for temporary employment and the protection of citizens working abroad.' Resolving the status of the workers in Denmark with the right to social security and pension insurance is regulated by bilateral agreements and conventions signed between the former Yugoslavia and Denmark in 1977. On the basis of international conventions and bilateral agreements 1980 the decision was also 'Law on the protection of the citizens of the former Yugoslavia to work abroad', and all decisions of the then party government of the former Yugoslavia, accompanied by the media. Can we confirm that the media is in some way immediate managing the lives of the future employees - migrant workers? Comprehensive picture of reality that surrounded them was created in large part based on the information from the media. One thing for sure, migrating workers, were watching a reality from another angle, they accepted most useful their families and find themselves in the whole story. 
Socialisation is the process of preparing for life in the community through acceptance of its core values, the process by which individuals engage in their structure the attitude and behaviour patterns of their respective social groups and society (Curran and Seaton, 1991). Considerable knowledge of the organisation of everyday life, civic values and behaviours by individuals and accepted through the media. Most of the important social experiences and derive mainly in direct contact with the events. As the quality of daily life depends more and more events that transcend space and time horizon individuals who directly control the experience, and the importance of media mediation becomes larger. This, however, does not mean that the media directly express the dominant ideology or that their influence is obvious and immediate (Snow, 1983).

Either way, the general principles revealed in the migratory movements of labour from Serbia and Montenegro, Denmark, coincide with those that took place in the former Yugoslavia. That's the most for the early ' 60 s, slow economic development of the country, as the most important factor and driver of emigration, it is dissatisfaction with living and working conditions, caused the decision of the Yugoslav workers to move to Denmark.

Immigrants from Serbia and Montenegro are therefore going to work temporarily in Denmark, with the intent to return when we have enough material resources to live in their homeland. However, there was dissolution of the former Yugoslavia, the economic blockade of the country of origin, so that the conditions for return have been more favourable, although more than 20 years past, and in the meantime, unplanned extended stay.

After the dissolution of Yugoslavia and the introduction of economic sanctions in the former Federal Republic of Yugoslavia, Denmark adopted rigorous laws for foreigners staying in the country, among others, those from Serbia and Montenegro. Citizens receive information through the media. The citizens of Serbia and Montenegro, if they want to come to Denmark, now have to have a visa. A visa does not give the right to work, and usually lasts for three months. And those who want to stay for more than three months, it is necessary to obtain the permit. Immigrants from Serbia and Montenegro, who have permanent residence in Denmark, I can based on the 'Law on Foreigners', to invite some close family members to reside in Denmark, if they meet certain conditions. That is, the so-called family reunification. A typical example, are spouses and minor children. A residence permit, is not given on the basis of marriage, which is not real, but it is made with a view to the applicant, provide a residence permit (http://www.nydanmark.dk).

In order to achieve family reunification, must meet certain conditions, depending on, which belongs to a group, such as the home or on the income of the local economic migrants. You can also set the requirement that both partners are older than 24 years and that their combined attachment to Denmark greater than attachment to another country. The aim of these requests by the Danes the protection of young people, against inappropriate marriage, of course, to provide the best possible starting point for the integration process. Permit permanent residence, can be obtained, first of all refugees, as well as those who come through family reunification. Those who have a permanent residence permit can after a number of years to obtain a permit unrestricted travel, if they tried to integrate into Danish society, otherwise comply with certain requirements. This means, among other things that they have no debt to the social authorities and had not committed any criminal offence (http://www.nydanmark.dk).

Permits an unlimited of stay for Serbian and Montenegrin migrants, just like to other foreigners, can be seized in a series of cases, for example, if specified basis for obtaining 
is incorrect, or no longer exists. Migrants who came to Denmark under family reunification, and no longer live with the partner but also a residence permit may be revoked and those who stop to live in Denmark, or go for a long time in the country of origin. As for coming, and for the stay in Denmark, respectively, to acquire Danish citizenship, you must meet certain criteria to the Danish Parliament, is determined. Specifically, according to the Danish Constitution, Parliament is the one who decides whether a person can become a Danish citizen or not. These criteria, including relationships, knowledge of the Danish language, documented confirmation of the Centre for Language Learning or certificate appropriate educational institutions, and a certificate of course the length of stay in Denmark. The starting point for obtaining Danish citizenship is at least 9 years of stay in the country, and for stateless persons and refugees, at least 8 years. Danish nationality can not get the person who committed the crime, or those who have debts to the state institutions (http://www.nydanmark.dk).

The Council of Ministers of the European Union, abolished 30.11 2009, visas for the citizens of Serbia and Montenegro. Ministers of Interior and Justice of the European Union, have adopted the amendment to Regulation 539/2001, which the citizens of Serbia and Montenegro, to put a 'positive Schengen list'. This means that the citizens of Serbia and Montenegro, since 19.122009 'exempted from visas' for European Union countries except Britain and Ireland. This, the decision of the Council of Ministers of the European Union, has caused a great deal of satisfaction and Serbia citizens of Montenegro, especially those whose families live in this Scandinavian country, which is now freely can visit their relatives in Denmark.

\section{The mass flow and migration}

Availability and comparability of migration statistics are the two most frequent and most serious questions about the collection of demographic data. In recent years, significantly increased efforts to improve the situation in this area, leading, if not the decisive, it certainly significant results (Bonifazi and Strozza, 2006). Salt (2005) notes that the availability of improved data, such as the collection methods are still inadequate, lacking a well-developed statistical systems. Although there has been significant progress in some countries in the region, the general picture is related to the availability of data is extremely fragmentary. Migration for employment was predominant type migration from the former Yugoslavia in Denmark by the end of the ' 90 s. This recruitment is being organised as we have already mentioned above in the text, mainly through the competent employment services ('Federal Bureau for employment'), on the basis of bilateral agreements with Denmark. But migration for employment took place spontaneously, through the channels of kinship and friendship relations. Before the " $60 \mathrm{~s}$, the eviction was not possible, because the legislation is restricting leave the country, and in this case it would be possible to speak about 'political emigrants'. According to the authors' knowledge of the text, among Montenegrin immigrants to Denmark, there was no single case of this kind.

For the former Yugoslavia and Serbia and Montenegro, we can establish the following emigration flows towards Denmark: Are first wave of emigration, since 1964 until 1991 that can be called 'maxi-formalisation phase' during which there is a liberalisation of obtaining passports and 'open borders policy'? The Federal Ministry for the former Yugoslavia issued in 1963 the 'Guidelines on employment of migrant workers abroad'. As noted Heršak $(1963,1985)$, the emphasis on 'temporary' residence is the idea 
that 'migrant workers abroad' is still part of the Yugoslav society and 'domestic working class'. A special role in the organisation of emigration, according to the 'guidelines', went to the municipal employment offices. In making a decision on issuing permits for work abroad, the departments should be mindful of the interests of the national economy and social services, and their needs for qualified personnel. Provides that a license issued by a rule only the unemployed and unskilled labour, while skilled and highly skilled workers were sent to work 'extremely, with the prior consent' of the Republic Institute for employment. "Guidelines' provides for the possibility of pension, disability and health insurance of the workers, and their families, if they would pay a prescribed amount in foreign currency. On the other hand, provides that 'foreign employers, agencies or organizations shall submit to the search for the employment', the Department for Employment" (Official Gazette of the SFRY, 1963). However, according to Dobrivojević (2007), it was concluded in party reports that Republican offices were 'not sufficiently trained to be able to practically apply the regulations' Guidelines on the employment of our people abroad. This is especially came to the fore in the unequal treatment of individual requests from abroad - while the department in one republic rejected an offer of employment, the Institute in the second it is accepted.

According to data, Rajović (2011c) relied on observations Lutovac (1975), and Rajović (1993, 2011b), we found interesting data that no one migrant from Montenegro, never made it to Denmark, with the help of the employment (The exception is the 17 migrants from central and northern part of Montenegro, who came to the assistance of the Bureau work on Jutland). Going to Denmark, immigrants from Montenegro, including a parent, author, mainly boiled over 'channels of kinship and friendship relations'. The Montenegrin migrants were mainly left to his relatives and friends, in which, the first time and live. And how much is already known and how people from Montenegro, one - helping others in everything. Total number of Yugoslav migrants in Denmark, is shown in the statistics on foreigners in 1991, volume 2 in the newsroom Bruun and Hamer (1991). The above statistics records are total number of Yugoslav migrants in Denmark in was $1967-358,1974-6802$ and $1991-10.039$. According to data, Rajović (1993) in Denmark in 1991 there were about 1.300 immigrants from Montenegro. According to rough estimates, the author of this article, the total number of migrants from Serbia in the same year was around 4.000.

Dobrivojević (2007) points out that the government hoped to Yugoslavia workers to work in Western European countries, to acquire certain knowledge and skills so that, after the eventual return, can easily turn into the economy. Is departure of workers abroad, benefited not only migrant workers but also their families and for the state? The third of the migrants are net earnings, or 2/3 savings, sent to Yugoslavia. O how much sums involved, evidenced by the fact that in 1971 year, remittances represented $57 \%$ of foreign exchange earnings is not visible. The state has not only benefited from remittances, but upon arriving at the home, where migrant workers are changing currency and buying goods for them, and often they have invested in the construction of utilities and infrastructure facilities in the homeland. The state is the migrant workers in foreign loans and saw the main stakeholders involved in technical goods uncompetitive in Western markets, but also for cars since their import was banned. Therefore, protective tariffs and favourable exchange rate of the diner against foreign currencies, migrant workers abroad, deterred from buying equipment abroad, as they were for the same amount of money could buy in the country. 
Authorities to Dobrivojević (2007) went a step further - he issued a decision approved sales of domestic goods for foreign currency, by stimulating the accounting rate increased by $20 \%$. However, goods that could be bought in this way has been carefully selected and defined, so that her choice was relatively narrow. It was an electrical system and a technical kind of household furniture, carpets, homes, prefabricated houses and agricultural machines, or, as in the case of apartments, solved the basic problems of existence. Despite the many positive spill over effects Yugoslav surplus labour in the developed European countries for the country and an economy that is increasingly weeping, communist in fear top of the 'negative' (political) consequences of the migration waves - 'harmful effects of returnees who have become rich' and 'the enemy of the possible effects on our country, our workers abroa'.

The second wave of emigration includes ' 90 s of the last century, the collapse of the Socialist Federation Republic of Yugoslavia, civil war, sanctions, and the overall situation of economic and social insecurity and hopelessness in Yugoslavia. Our research evidence based on similar research Antonijević et al. (2011), suggests the following. Specifically, this emigration wave is characterised by two types of migrants. One completely new migrants, people in the younger and middle age who had never wanted or thought about going to Denmark, who had in the Federal Republic of Yugoslavia, a job and a decent income, but they have lost jobs, poor and decided to 'better life' in Denmark. In all this facilitated their emigration from the previous wave, relatives or friends who could help them about arranging visas, finding a job and making their way in a new life. It is not known how many were deliberately gone 'forever', and how many have their residence in Denmark, is considered 'temporary'. This wave, on the other hand, is characterised by departure to Denmark and children who had previously lived in their homeland and joins their parent's migrants. While in earlier waves, the children were left to 'keep house' and live with grandparents, in this period, parents are immigrants, for fear of the situation in the former Yugoslavia, along with the water. Most parents, our first take the citizenship of Denmark, in this way, their children facilitating the issue of visas and permanent residence permits.

"The third wave of emigration was built in 2000 year, that is, after the
democratic changes in Serbia. About this migratory wave to at least speak, as a
'silent' criticism of are regime in Serbia, with respect, that the changes have not
occurred, or as fast or as far as promised and expected. Areas in Serbia are
traditionally known as emigration continued to 'export' a workforce that still
does not see their future in the country. Regardless of the level of education and
type of job you are forced to work, "package' your bags and go to the countries
where they guaranteed economic stability, or so it seems to them" (Antonijević
et al, 2011).

In Denmark distinctive as before the ' $90 \mathrm{~s}$, mostly coming from certain workforce regions in Serbia and Montenegro, and there are primarily distinguished: region of northeast Serbia and northern Montenegro. This wave is characterised by the following facts: it is mainly the young people who are either very young children or children born in the country of immigration, and that for now they see no incentive to return to Serbia and Montenegro. They mainly are, in fact, true migrants with the idea to make your stay abroad a permanent, not temporary. This wave has the greatest difficulties and obstacles in obtaining visas and residence permits in previous generations of migrants, since the policy of Denmark, has changed compared to the migrants from the former Yugoslavia and changed the economic situation and in the Denmark (Antonijević et al., 2011). 
Figure 1 Visiting in Denmark - author near the NØrrebro Bycenter (June 2012) (see online version for colours)

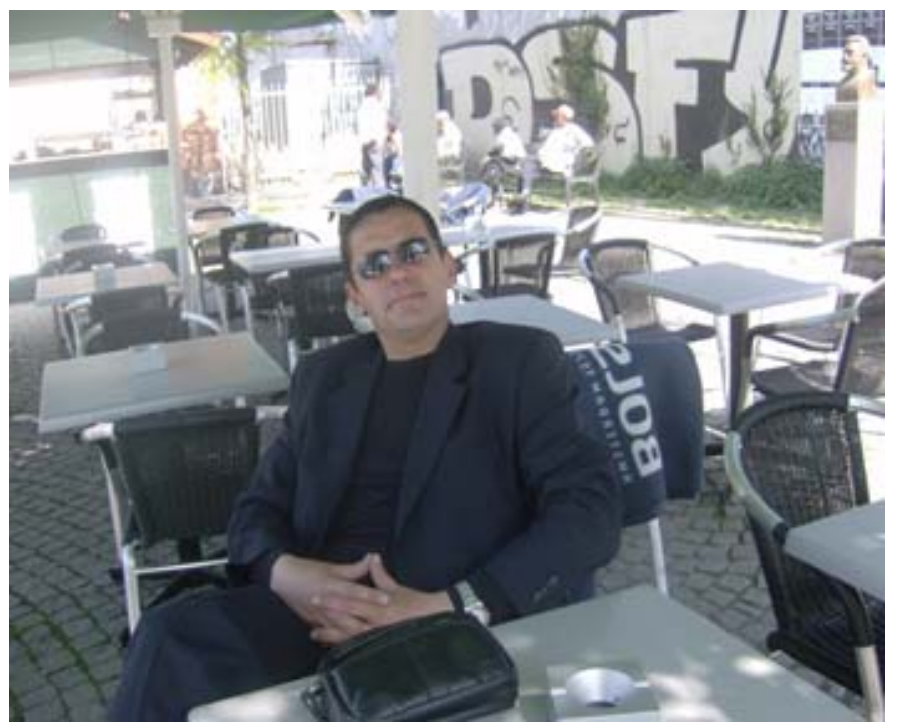

However, at the end of the '90s, the migration flows from the former Yugoslavia in Denmark take on new forms, and (new) categories of migrants. In the years before the Yugoslav crisis, after the break-up of the Socialist Federal Republic of Yugoslavia under the influence of the civil war, refugees (and/or) false asylum seekers seeking refuge in the territory of Denmark. So, in fact, economic migrants from the former Yugoslavia declared as refugees and asylum seekers: 'False and real refugees have become one of the opportunities to go abroad for employment and', and therefore in Denmark. According to data Bonifazi (2011), during the period from 1990 to $2004-35.331$ persons from are former Yugoslavia, sought asylum in Denmark. From Serbia and Montenegro asylum in Denmark (in thousands) submitted during time periods: 1990-1994 (5.8), 1995-1999 (6.3) and 2000-2004 (5.2). Regardless of the downward trend, the number of applications the applicant from Serbia and Montenegro to Denmark for asylum, stayed at a very high level of about 5,200 claims.

According to are United Nations Convention on Refugees from 1951, which was also signed by Denmark, refugees cannot be returned to their country of origin if they think that their life is in danger or the threat of persecution. 'This right is called the' right to prohibit expulsion ('non-refoulement'). According to Hovy (2011), the total number of refugees from Serbia and Montenegro, the receiving country (Denmark) in 2004 was 4,880 .

The exact number of migrants Serbia and Montenegro and their descendants around the world, including in Denmark, it is certain, that we cannot have definitive data. The fact is that there is no institution in Serbia and Montenegro, which has accurate data on the number of immigrants from Serbia and Montenegro abroad, even in Denmark. However, all agree that the number is not small, and it is increasing every year. Embassy of the State Union of Serbia and Montenegro in Copenhagen in early 2005, an estimate that lives in Denmark about 6,000 immigrants from Serbia and around 2,000 migrants from Montenegro(Yugoslav workers on temporary work and residence in Denmark - 
migrants 'as a legally recognised populations of migrant origin'). According to the statement of Ambassador of the State Union Serbia and Montenegro in Copenhagen Vladimir Radulović (2005): it's hard to say how many of our people have citizenship of Serbia and Montenegro, because it is in meanwhile, $40 \%-50 \%$ of citizens of Serbia and Montenegro accept Danish citizenship. According to Danish law on citizenship, it was necessary to give up their previous citizenship, it is the citizenship of Serbia and Montenegro (http://www.blic.evropa.net). Simply because what Danish law on citizenship not accept status the dual citizenship. Ministry for Human Rights and Refugees of Bosnia and Herzegovina (2008), referring to the data of Danish Bureau of Immigration for 2005 year, cite the fact that in the period from 1995 to 2004. Danish nationality gained 14,412 people, who came to Denmark from the former Yugoslavia, and it is certain that in this group have found their place and are those who are descended from Serbia and Montenegro.

\section{Stay in Denmark and the tangible effects of migration}

Nearly 50 years have passed since the arrival of the first generation of migrants today from Serbia and Montenegro in Denmark, so that these people and their families showed and proved, that with all the problems they had, and certainly were not small, manage their work, to survive in the soil and cause numerous Danish sympathies to the Danes themselves, and all others. Thanks to his organisational skills, many migrants from Serbia and Montenegro have become highly productive workforce in Denmark. Today, they are the ones who: manage; make decisions, hire and products.

Migrants from Serbia and Montenegro, it is the first generation of migrants, mostly from Timok and northern Montenegro began arriving in 1964 into one of them brand new and the natural and social environment, as it was Denmark. You can hardly be imagined greater extremes: from a height of several hundred or even thousands of feet, migrants from Serbia and Montenegro went to the Danish plains. They left their agricultural lands, and included in the Danish industrial factories. And all the other circumstances, ranging from climate and soil composition, and housing through the various psychological elements of life were so different, hence the great many challenges.

New residents of Denmark have faced, especially in the beginning, and many other difficulties. Felt they were already on the front steps, travelling to Denmark and four to five days, with small children in their arms or taking them in hand, and carrying in their bags, only some food for the journey and personal wardrobe. No less were no problems getting used to the new way of employment, housing, nutrition and lack of knowledge of the Danish language, the uncertainty in the work, homesickness and loneliness.

As one explains it all respondents surveyed are Stamena Rajović (first generation immigrants, born in 1944), lives and works in Denmark since 1971. Now is pensioner in Denmark.

"I came to Denmark with her two little children, one aged two years old and the other ten months, my husband arrived a year ago. I first accommodation with relatives, our family of four are a two-room apartment. I did not know a word of Danish language, I did not know the laws, customs, and I was pretty sceptical about my and our future in this country. The first step in the integration of my job was that I immediately got in the factory 'FarmaPlast' which is involved in the manufacture of medical products. The factory was already six Yugoslavs (from Montenegro and Macedonia). On the one hand it was good because I had someone to talk in their native language, to joke and 
laugh at the break, but on the other hand I had the problem of knowing the Danish language. Now comes are organisation. Husband works first shift, and I the other, to be home organised around child care. When I possibly independently learned the Danish language, so that they can go alone to go shopping, to find my way in the carriage, to go to the doctor, to communicate with the heads of the plant and therefore Danes, my happiness knew no bounds. All of us in Yugoslavia in Denmark we have 'arrived with suitcases packed', and we intend to remain in the long run. I always thought of return. And because of that, many of us have taken your family. When both parents were in Denmark, children are most likely to stay with my grandmother and grandfathers in Yugoslavia. And so it was in our case. In Denmark we have two more kids, but when it came time for school, we returned them to their homeland, the blanket, grandmother and aunt. We worked two shifts, and after five years, we have received a visa, embedded in passports, as well as special cards, called work visa. Initially we wanted to stay in Denmark while the children do not go to school, and then wait until they finish school. The economic crisis, are civil war in the former Yugoslavia, international isolation, changing everything. So from our four-children, two eighteenth before are returned to Denmark. In the meantime, we are old and I started here to receive pensions".

Figure 2 Our interviewee in Denmark-Stamena Rajović (see online version for colours)

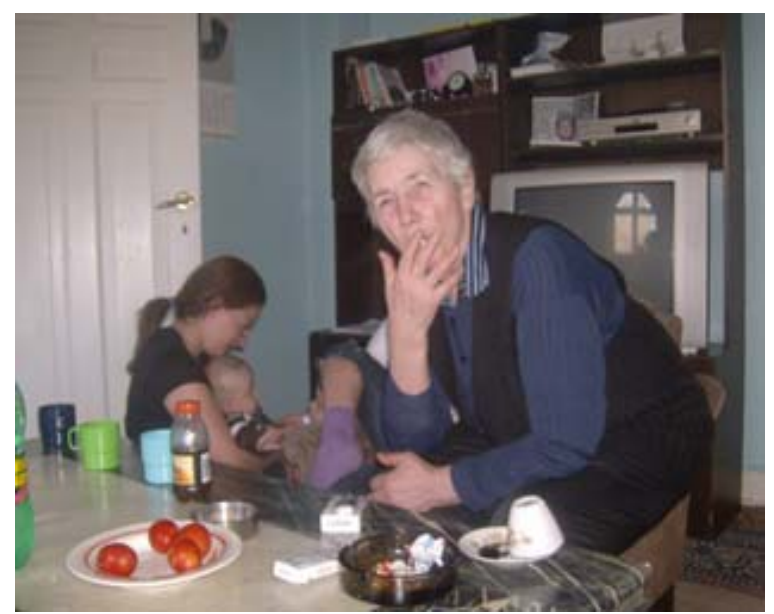

The main driving force throughout this journey was undoubtedly Danish society. Unfortunately, in this study, the variety of aid could be discussed only briefly and incidentally, just enough to indicate its presence. And what are the specific perceptions these respondents surveyed:

"The Danes are extremely accurate. Rarely do they happen to be late for work or a meeting. If it does happen, will inform you of this at the time because the Danes do not want to inconvenience you have for them, as you would not want even they, have the inconvenience for you. Danes are friendly people. Of course, they have their limits because they are primarily devoted to their families, so do not spend too much time for others. However, if you show are desire for companionship, will not remain unrequited. What is inherent in naturally Danes kindness in dealing? It is certainly refreshing to man. Of course she is not infinite, but it is not artificial. When you ask 'How are you?' accompanied by a smile, and usually expect an answer. Morale of are Danes at a high level. Such work and attitude to work, this small country in terms of 


\begin{abstract}
population, but according to the wisdom and great work, classified as a first in the world in production of meat, milk, eggs and other agro - food products. Accustomed to the business discipline and clarity in observation, Danish employers have enthusiastically embraced our work force in Yugoslavia in the workplace, and of course their willingness, energy, cheerfulness, sense of reality, and everything in terms of adjusting to a new lifestyle. Danish employers and how you perceive the Yugoslavs, more tact, a sense of humour. Everything that they do not like, they reveal Yugoslavs jokes and humour. On the other hand, in our workers themselves Yugoslavs, the ratio of the Danish employers occurs in the form of appreciation for the provided services, which often turned into almost boundless confidence. In Denmark, there is a positive relationship between the Danes themselves, to respect the law and it goes to the point that I'm proud of Dane. And at the end of life is the safety aspect of the Danish way of life that man is simply fascinating. Dane all planned in advance and does not do anything in haste. Many Danes vacation application head for the entire year in advance. In the end, I do not know what would have been a completely reliable evidence of integration into Danish society. I guess - when one begins to think, much like the host country to which you moved".
\end{abstract}

The analysis of personal narratives about the experience of living and working, first-generation immigrants from Serbia and Montenegro in Denmark is the notion that migrants living abroad often do not coincide with the image that community members have about them in their homeland. Hard work, poor living conditions, poor knowledge of the language, customs and culture, marked by years and years of first-generation immigrants from Serbia and Montenegro in Denmark. Patriarchal family model, the concept of marriage and parenthood, are replaced by pragmatic solutions, dictated by fate and survival of migrants in countries of departure, as well as their legal and regulatory system. Keep children in the homeland of the care grandparents, are a clear indicator of the impact of the traditional patriarchal system of values and western market. So the first generation of migrant life is carried out, in fact, the gap between the desire to provide material well-being for children and the inability to actually be parents. Most first-generation immigrants from Serbia and Montenegro to Denmark returns home after retirement, or leaving Denmark with tangible benefits provided by the Danish government recently, but no children. One thing is certain; these people have had honourable, honest intentions and patriotic feelings. Unfortunately, assistance from the country of origin did not have and for them still axiom 'neither here nor there'. Importance in the lives of first-generation migrants are family relationships and ties of mutual assistance, usually a relative or close friend, who received them in Denmark and helped them to find their way in the beginning, but here we must take into account social security that provides country Denmark.

Social security in this Scandinavian country, in the broadest sense of the word, it means creating equal opportunities for individuals in this country, that you and your family can provide the conditions of life, which will give them a chance to meet their basic needs and derived. In institutional terms, social security is the foundation of the organisation of the state of Denmark with all institutions that provide such capabilities. Also the safety aspect of life as the Danish way of life implies the stability of social status, material and cultural living conditions, the production and reproduction of life, the creation of conditions for the performance of work and social roles. This includes prevention and risk reduction or deterioration of water conditions for life and work: individuals, families, community groups and organisations. Very widely understood term in the Danish society, which stands for are complex application of human rights. Danish 
society implies an obligation to provide every individual and guarantee the physical integrity and the proper education, the creation of conditions of employment and housing, as well as legal certainty in some cases, loss of capacity, particularly the capacity for self-managing.

Eliade (2002), she claims that there will always be naturalised links between people and places (territories) of her birth, which shows a tendency to affiliation and identity of the individual (and group) associated with a particular territory, whether that place of birth, hometown or expanding homeland. A person is identified with the concept of space, the ground on which he lives, that is, where she was born. The idea that people are 'being places' (Eliade, 2002) is often expressed by means of botanical metaphors and talk about 'rooting' in place, that is, when it abandoned the 'eradication' (Handlin, 2002). Sled such displays, passenger-migrant, will seek his return to his homeland, and reintegration into society of immigration, in which 'the nature of things' after a while feels good and where it is accepted, it should be an easy process and not conflicting.

Today, migrants from Serbia and Montenegro in Denmark are great success in every way, from his personal, family to social. By what can be seen and see the standard of living of migrants Serbia and Montenegro in Denmark is indeed high. Almost all of them have very nice comfortable apartments, equipped with modern furniture and white goods. Individually each family owns a car. From the individual interviews, we learned that most of them have built houses in the homeland or purchased condos and office space owners are predominantly: Belgrade, Novi Sad, Podgorica, Montenegrin coast.

Immigrants from Serbia and Montenegro to Denmark as a significant factor in financial remittances over are stability of their families, relatives, friends and even homeland. According to Vasiljević (2009), the statistical definition used by the International Monetary Fund, the methodology of data collection and analysis of the balance of payments, remittances meant by: workers 'remittances, relating to transfers of migrants employed for more than one year in countries outside the country of nationality, wages (compensation of employees), which include wages, salaries and other benefits migrants (including seasonal and temporary work) was out of the country of which they are nationals and migrant transfers, which represents the transfer of assets in the event of permanent emigration.

Research remittances are formulated several basic motives that govern migrants sending remittances. The main motive is to help the family who lives in the country of origin. It refers not only to finance consumption of the family, and the cost of maintaining the family property. Second, remittances may be directed to financing the construction of houses, purchase flats or editing space that migrant wants to have available after returning from abroad. Third, remittances financed assets intended to generate income, such as the purchase of a business or residential space. Fourth, remittances are sent for the opening of business ventures or investments in existing companies. Finally, the motive for sending remittances may be philanthropic, to help the church, social projects or activities of local government.

According to Petree and Baruah (2006) are apparent tendency to large volume of remittances is channelled into the construction of houses, which is not an expression of a real need for improved housing or economically justified investment, since the houses were built in areas where they have little or no market value, there is a demand for extradition. Patterns of use of remittances of migrants from the first wave of migration only slightly in the type of migrant households express, to a large extent conditioned by 
the desire to realise the prestige in the local environment, in the villages can be easily seen buildings that belonging to migrant families.

Given that we do not have exact data on the share of remittances Serbian and Montenegrin Diaspora from Denmark to Serbia and Montenegro, we will use the official data, but the overall participation of the Serbian and Montenegrin Diaspora in the financial stability of their country. According to the figures, Pissarides et al. (2006), Serbia is the volume of remittances in 2004 among the 11 largest recipients of remittances in the world, according to a share of remittances in GDP is at 8 in the world. On the other hand, for the first 11 months of 2012, the Montenegrin Diaspora has been sent to Montenegro, close to 258 million Euros (http://www.kamatica.com).

A number of migrants, and has a personal savings 'old savings' that they had been frozen 27.041991 and today stand as impaired. Foreign depositors to assess the latest Act of 2004 on the return of funds by 2017 does not mean anything to them, because they highlight how many of them will be alive and the time does not work for them (first generation immigrants). The problem of payment of old foreign currency savings seriously compromises any attempt to renewed interest in saving migrants in Serbia and Montenegro. It is certain that migrants will not invest money in banks in Serbia and Montenegro, while the old savers do not pay their roles. Just as states and banks can regain credibility and trust with immigrants and consent by the savings in banks in Serbia and Montenegro.

One important cause of this situation is related to the banking system and, on the way to work today, and its ownership structure. Banks and uncompromisingly pursue only are their own profit interests, mostly short-term. Interest and commissions in Serbia and Montenegro are among the highest in Europe. Loans to hang directed where the bank can earn a maximum of (cash loans), and where the repayment of the loan can easily ensure mortgage loans, securities of the National Bank....

Diaspora is, unfortunately, a very serious matter. In the world, there are over three million.... citizens of Serbia and Montenegro. In light of the fact that Serbia and Montenegro small country, it is very big spread. The translation of the language of numbers is that one in three or something more ... a citizen of Serbia and Montenegro, living abroad. These people each year sent or brought to Serbia and Montenegro, at least 3.5 billion Euros. Serbia and Montenegro from are, in fact, alive. Among these people there are quite a number of successful, from science to big business. They can really help a lot. But are how? These people simply do not have access to Serbia. They do not belong to any political party.... That is the reality. And many of them would want to go back..... But are how..........? (http://www.vesti.rs/izvor/SrbijaNet).

\section{Conclusions}

Our research evidence pointed to the forefront, concluding several important facts: Sources for the study of migration from the former Yugoslavia are numerous, but they are often inconsistent, incomplete and methodologically flawed. In addition, it should be noted that the credibility of their dependent and ideological background of some migration to the country of origin and the receiving country, which of course is true for immigrants from Serbia and Montenegro in Denmark. This is particularly true of national self-declaration, which is the true picture was blurred long and in many ways the 
suggested 'Yugoslav identity', so that the nationality of those who were on the lists themselves as Yugoslavs, can be judged only on the basis of specific area from which they migrated (Davidović, 1994).

The main statistical source for the study foreign migration abroad, and therefore in Denmark, is a list of the population, with all its defects, as well as reports of embassies and consular offices of the state in which they left the citizens of the former Yugoslavia, then reports and assessments of Yugoslav or Consulate of Serbia and Montenegro in Copenhagen and censuses immigration countries, as well as bilateral and international agreements on employment and protect migrant workers abroad.

In previous investigations of contemporary labour migration abroad, the emphasis is mainly placed on natural geographic and demographic aspects of migration and the question of national and cultural identity.... and all fundamental through research and direct contact with the Yugoslav and migrants from Serbia and Montenegro (Pavićević, 2004).

Either way, the contemporary labour migration from Serbia and Montenegro in Denmark is characterised by the following:

Since the very beginning of migration immigrants from the former Yugoslavia, Denmark's state as well as its policy of cultural pluralism, allow freedom of expression and practice of ethnic identity, and the verification of that liberalism is evident through the presence of many associations and clubs, who acted and acts in many places in Denmark: 'Džemal Bijedić', 'Đerdap', 'Branko Ćopić', 'Timok', 'Edvard Kardelj', 'Kadinjača', 'Veljko Vlahović', 'Serbian club', 'Montenegro', 'Besa', 'Ilirija', 'Macedonia', 'Ivo Lola Ribar'. The number of clubs clearly demonstrates how migrants attributed social organisation and the importance of fostering diversity. Awareness of the need for companionship, friendship conservation, cultivation of different crops and other assets, has done is to create and Denmark - Serbian cultural and sports associations in Hillerød and Næstved.

Migrants from the former Yugoslavia, due to 'chain migration' almost always inhabit the same or adjacent areas, and mainly: Copenhagen, Hillerød, Frederikshavn, Helsingør, Næstved, Silkeborg..... in the first phase of life in the new space, they rely on each other, because of ignorance of the Danish language. Mother tongues just their main symbol of identity and can be seen in the new circumstances and as inclusive as exclusive (Ryan, 1979). Starting from the socio-linguistic assumption that the primary contact realise possible through language (Rosenberg, 1992), may provide the answer and why to this day, held numerous clubs and societies in the former Yugoslavia in Denmark.

Socio-linguistic sciences " 60 s and ' 70 s was clearly laid out the criteria by which it is possible to determine the degree of preservation of identity through language, through the so-called clear formula "to anyone who speaks which language, where and in what situation?" (Fishman, 1966). The study of language in everyday life confirms a clear picture language setting above-mentioned authors, that certainly holds true for immigrants from the former Yugoslavia, and the day and the language within it are domains: parents - house, intimate - its own identity, free time - social life (church, media); workplace - shopping, neighbourhood; education; husband - partner and intergenerational communication (grandmother or grandfather - grandson).

On this occasion, I point out at the end the following: First-generation migrants from Serbia and Montenegro in Denmark (mostly men), characterised by a planned temporary stay, which in most cases extended in a manner that is brought to her husband, and then the whole family, within which are mostly children continued their education in 
Denmark. Contacts first-generation migrants from Serbia and Montenegro with their homeland, they were very frequent visits to the country, investing saved funds to buy the most: housing, cars, property, construction of houses in the homeland, visiting relatives.....so that the integration could be harder to get.

Situation with members of the second generation is much different. They are confronted with two cultures; increasingly adopting the language and value system of the country where they live, what they ultimately facilitates and enables social mobility.

In Denmark, the form and third generation migrants from Serbia and Montenegro, significantly different from the first, more integrated into Danish society than the other, so that the phenomenon of gender, unlikely to be decisive for the future, at least not in large numbers, while the only recent organised remedial classes, offering opportunities to learn their language, geography, history and music education.

Denmark is a prime example of the state where the persistent and deliberate work, culture and democracy achieved legally, economically, socially stable society, appealing to other countries and peoples. In such a society, that I have found my place and migrants from Serbia and Montenegro, that the Danes have a lot of sympathy, which is understandable when the Danes themselves strike correctness of Slovenia's emotions.

\section{References}

Antonijević, D., Grubešić-Binić, I. and Krstić, M. (2011) 'Foreign workers - from their point of view. Narratives and the socio-economic situation of foreign workers', Journal Ethno-anthropological Problem, Vol. 6, No. 4, pp.983-1011.

Banović, B. (1982) Emigration from Yugoslavia and the Yugoslav Immigration to New Zealand, $\mathrm{PhD}$ thesis, (manuscript), Ljubljana.

Bonifazi, C. (2011) 'International Migration in the Balkans since the end of the Cold War: overview', in Penev, G. (Ed.): Migration, Crisis and Wars in the Balkans in the Late Twentieth Century, Company Demographers Serbia, pp.5-25.

Bonifazi, C. and Strozza, S. (2006) 'Conceptual framework and data collection in international migration', in G. Caselli, J. Vallin and G. Wunsch (Eds.): Demography: Analysis and Synthesis, Vol. IV, Elsevier, San Diego.

Bošković-Stulli, M. (1984) 'Narratives - the problems of contemporary oral literary genres', in Bošković-Stulli, M. (Ed.): Oral Poetry in the Literary Horizon, pp.309-366, Publishing Institute Croatian, London.

Brettell, C.B. and Hollifield, J.F. (2007) Migration Theory: Talking Across Disciplines, Rutledge, New York-London.

Bruun, I. and Hamer, O. (1991) 'Statistikker over udlændinge, ingen sekunder', Danmarks statistik 1991.ar.

Čapo-Šmegić, J. (2006) Ethnology, Talk [online] http://www.svjetlorijeci.ba (accessed 2 March 2013).

Castels, S. (2006) 'Guest workers in Europe: a resurrection?', International Migration Review, Vol. 40, No. 4, pp.741-746.

Clements, W.M. (1980) 'Personal narrative, the interview context, and the question of tradition', Western Folklore, Vol. 39, No. 2, pp.106-112.

Curran, J. and Seaton, J. (1991) Power without Responsibility, Rutledge, London.

Davidović, D. (1994) 'The role of tradition in structuring the cultural identity of Serb immigrants in Western Europe', Journal of Ethnographic Institute of the Serbian Academy of Sciences and Arts, No. 43, pp.101-109. 
De Hass, H. (2005) 'International migration, remintaceas and development, myths band facts', Third World Quarterly, Vol. 26, No. 8, pp.1629-1284.

Dobrivojević, I. (2007) 'Looking for well-being - going Yugoslav nationals to work in Western Europe 1960-1977', History of the Twentieth Century, Vol. 25, No. 2, pp.89-100.

Dušanić, J. (2011) 'Is it possible to stop further destruction of economy of Serbia?', Economic Policy, 2011-09-01 [online] http://crms.org.rs (accessed 24 February 2013).

Eliade, M. (2002) Sacred and Profane, 'AGM', Zagreb.

Fishman, J. (1966) Language Loyalty in the United States, p.425, The Hague, Mouton.

Group by (2006) 'Montenegrin Diaspora', Proceedings of the Montenegrin Association Foundation, The Centre for expatriates of Montenegro, Podgorica.

Handlin, O. (2002) The Uprooted. The Epic Story of the Great Migrations that Made the American People, University of Pennsylvania Press, Philadelphia.

Heršak, E. (1963) 'Instructions on employment of our workers abroad', The Official Gazette, The Socialist Federal Republic of Yugoslavia, October, No. 42, p.23, Belgrade.

Heršak, E. (1985) 'Postwar migration perspective of Europe', Migration Journal Topics, Vol. 1, No. 1, pp.5-20.

Horvat, B. (1969) Essays on the Yugoslav society, 'Youth', Belgrade.

Hovy, B. (2011) 'How many of them have left the country? Displacement of citizens of the former Yugoslavia', in Penev, G. (Ed.): Migration, Crisis and Wars in the Balkans in the Late Twentieth Century, Company Demographers Serbia, pp.27-47.

Jambrešić-Kirin, R. (1995) 'Testimony and historical memory: the narrative mediation of personal experience', National Arts, Vol. 32, No. 2, pp.165-187.

Kovačević, I. and Krstić, M. (2011) 'Between history and modernity: an anthropological study lows foreign workers in the 21 century', Journal Ethno-Anthropological Problem, Vol. 4, No. 6, pp.969-981.

Kuznetsov, J. (2006) Diaspora Networks and the international Migration of Skills, How Countries Can Drawn on Theiler Talent Abroad, The world Bank, Washington, DC.

Lebowitz, M. (2010) Lessons of Yugoslav Self-management [online] http://www.nodo50.org (accessed 26 February 2013).

Lee, E.S. (1966) 'A theory of migration', Demography, Vol. 3, No. 1, pp.47-57.

Lutovac, V.M. (1975) Labor Migration Montenegro to Temporary Work Abroad, PhD thesis, (manuscript), Belgrade.

Madžar, L.D. (2000) 'A singular constraint on the economic development of the FR Yugoslavia', in A Liberating Economic Journey: Post-Communist Transition, Essays in Honor of Ljubo Sirc, Centre for Research into Post-Communist Economies, London.

Milanović, B. (1990) Economic Inequality in Yugoslavia, Institute of Economics, Belgrade.

Nikitović, V. (2009) 'Serbian-country immigration as expected future?', Journal of Population, Vol. 47, No. 2, pp.31-52.

Official Gazette of the SFRY (1963) Instructions on Employment Our from Workers Abroad, No. 42, 23 October, Belgrade.

Pavićević, A. (2004) 'Some questions outside the Yugoslav population migration during the second half of the twentieth century - time for reconsideration?', Journal of Ethnographic Institute of the Serbian Academy of Sciences and Arts, Vol. 52, pp.129-137.

Penev, G. and Predojević-Despić, J. (2012) 'Spatial accepts of emigration out of Serbia, three 'hot' emigration zones', Journal Population, Vol. 50, No. 2, pp.35-64.

Petree, J. and Baruah, N. (2006) A Study of Migrant-Sending Households in Serbia-Montenegro Receiving Remittances from Switzerland, pp.25-26, International Organization for Migration, Geneva.

Pissarides, R., Sanfey, P. and Tashchilova, S. (2006) 'Financing transition through remittances in south-eastern Europe: the case of Serbia', EBRD, p.6. 
Radulović, S.V. (2005) Ambassador of the State Union Serbia and Montenegro in the Copenhagen Newspaper 'Blic' [online] http://www.blic.evropa.net (accessed 26 August 2005).

Rajović, G. (1999) 'Country Denmark - the world of in the small', Popular Science Proceedings 'Land and People', Serbian Geographical Society, Vol. 49, pp.50-52.

Rajović, G. (2000) 'Jutland - Europe in miniature', Revue Field, No. 72, pp.31-32.

Rajović, G. (2001) 'Finland-country of midnight sun', Popular Science Proceedings 'Land and People', Serbian Geographical Society, No. 51, pp.45-46.

Rajović, G. (2011a) 'Demographic characteristics of the modern labor migration from Montenegro to Denmark', Journal GeoScape, Vol. 6, Nos. 1-2, pp.2-10.

Rajović, G. (2011b) Montenegrin Immigrants in Denmark, 'The Agency PC system', Belgrade

Rajović, G. (2013) 'Some socio-geographic characteristics of modern labor migration from Serbia and Montenegro to Denmark: social life and social relations migrants', International Letters of Social and Humanistic Sciences, No. 2, pp.1-17.

Rajović, V. (1993) Montenegrins in Denmark, 'Unireh', Nikšić.

Robinson, J. (1981) 'Personal narratives reconsidered', Journal of American Folklore, Vol. 94, No. 371, pp.58-85.

Rodić, P.D. (1971) 'Labor migration from Serbia in the Federal Republic of Germany', Journal of Science University of Belgrade Institute of Geography, No. 18, pp.143-159.

Rodić, P.D. (1972) 'Some socio-geographical problems of the contemporary labor migration abroad of Yugoslavia (1961-1971)', Journal of Science University of Belgrade Institute of Geography, No. 19, pp.63-80.

Rosenberg, P. (1992) Sprache und Identität, in: Die Russlanddeutschen - Gesternund Heute, ed, Boris Meissner - Helmut Neuberger - Alfred Eisfeld, Cologne, pp.217-238.

Ryan, E.B. (1979) 'Why do low - prestige language varieties persist?', in Language and Social Psychology, p.147, Oxford.

Salt, J. (2005) Current Trends in International Migration in Europe, Council of Europe, Strasbourg.

Serbian Information Network (2010) Manipulation of Diaspora of Serbia [online] http://www.vesti.rs/izvor/SrbijaNet/ (accessed 2 March 2013).

Skeldon, R. (2008) 'International migration a toll in development policy: a passing phase', Population and Development Review, Vol. 34, No. 1, pp.1-18.

Snow, R.P. (1983) Creating Media Culture, Sage, Beverly Hills.

Spasović, S. and Miletić, S. (2010) Sense of Identity and Diaspora [online] http://svetosavlje.org (accessed 28 February 2013).

Stahl, S. (1977) 'The personal narrative as folklore', Journal of Folklore Institute, Vol. 14, Nos. 1-2, pp.9-30.

Stark, L. (2005) 'Invisible narratives in the construction of past and present', Ethnologic Fennica, Vol. 32, pp.44-47.

Stojanović, B. (2005) Transition in Serbia - Commercial Wandering, Institute for European Studies, Belgrade.

Titon, J.T. (1980) 'The life story', Journal of American Folklore, Vol. 93, No. 369, pp.276-292.

Tomaš, R. (1993) Fear of Entrepreneurship, Economics, Belgrade.

Tucović, O. and Stevanović, R. (2007) 'Natural population of Belgrade in the second half of the twentieth and early twenty-first century', Proceedings Geographical Institute 'Jovan Cvijić' Serbian Academy of Sciences and Arts, Vol. 57, p.144.

Vasiljević, B. (2009) 'Impact of remittances on economic and social development in Serbia political theory, political sociology, political system', Yearbook of the Faculty of Political Science, Part I, pp.202-213.

Vukčević, M. (2006) 'Causes and general characteristics of the Montenegrin Diaspora', Proceedings of the Montenegrin Diaspora, Centre for Expatriates of Montenegro, Podgorica. 